\title{
EMPLOYEE DEVELOPMENT AND LEADERSHIP PERCEPTION IN THE POLISH SERVICE DELIVERY CENTRES
}

\author{
Damian KEDZIORA*, Wojciech PIOTROWICZ**, Katarzyna KOLASINSKA-MORAWSKA*** \\ *Maria Curie-Sklodowska University in Lublin, POLAND \\ e-mail: damiankedziora@gmail.com \\ **Hanken School of Economics, Helsinki, FINLAND \\ e-mail: wojciech.piotrowicz@hanken.fi \\ ***University of Social Sciences, Lodz, POLAND \\ e-mail: kkolasinska@spoleczna.pl
}

\begin{abstract}
The rapid growth of modern services industry in Poland, observed in the past few years, has been substantially determined by the vast talent pool of well-qualified and cost-efficient workers. The intensive expansion of the industry has been aligned with widely implemented policies of personal development and leadership, aimed to grow and prepare internal human resources for more challenging roles in newly established projects and teams. The paper presents the results of empirical research examining the perception of those schemes and policies, from the perspective of workers employed in the polish offshore service delivery centers.
\end{abstract}

Keywords: modern, service, offshoring, outsourcing, human, resources, leadership, personal, development.

JEL: M16.

\section{$1 \quad$ Introduction}

Across the past decade, business process offshoring industry has been dynamically growing in the Central and Eastern Europe (CEE), particularly in Poland that holds a position of regional leader, with over 240,000 employees delivering remote processes in over 700 modern services centers (ABSL, 2017).

The processes transferred have been of diverse business domains, like accounting (account receivable, payable, general ledger), information technology (coding and application development, remote infrastructure management, service desk support), banking (account transaction, loans, capital markets), customer service, order management, as well as higher education (Kedziora, et al., 2017c).

Such transnational transformations on the global and European services market are often motivated by cost reduction, overcoming organizational inefficiency and optimization of service performance (Kedziora, et al., 2016).

One of the key factors facilitating the rapid growth of jobs shifted to the newly established delivery centers in Poland, has been the availability of the highquality workforce supply. The demand for human capital employed in the industry puts key emphasis on the educational background (particularly in the business and tech studies), language skills (mostly English and German, but also niche languages), and the leadership potential as well (PIaFIA, 2016).

Therefore, many organizations have been implementing multiple strategies of Employer Branding and Human Development, in order to maintain and grow key workers from the perspective of organizational performance (ProProgressio, 2016). At the same time, significant business and research centers point at the challenges affecting development of future leaders globally. According to a recent Deloitte human capital report, personal development is still a significant challenge for many organizations, as the digital transition creates even larger leadership gaps (Deloitte, 2017).

This work aims at addressing the situation of workers building and representing Polish modern services sector, from the perspective of their opportunity to grow and enhance personal potential. It is an exploratory, pilot attempt to study the employee development and leadership conditions in the business process outsourcing and shared services centers (BPO/SSC) that have not yet been explored in the 
available academic research. Therefore, the paper shall address the following research questions:

1) What is the employees' perception of personal development opportunities?

2) What is the employees' perception of direct leaders' engagement?

\section{Literature review}

The literature review consists of three interconnected parts that primarily stems from the management discipline; incorporating in addition papers from journals related to managerial psychology studies, international business and organizational management. Firstly, the main concepts related to employee development and job satisfaction are discussed. Secondly, based on the literature, the concept of leadership in a socioeconomic context is presented.

In the end of this chapter, the authors elaborate on the $\mathrm{BPO} / \mathrm{SSC}$ industry in Poland as a work environment for its employees.

\subsection{Employee development and job satisfaction}

Employee development may be diverse in form and may include the following aspects:

1) trainings related to work;

2) trainings not related directly to work;

3) assessments and feedback;

4) promotions and enlargements of responsibility scope;

5) relationship among workers;

6) career planning actions;

7) projects and work-group (Pierce and Maurer, 2009).

Investing in the development of employees is crucial in developing and maintaining the knowledge, skills and abilities of both individual workers and the organization as a whole (Kuvaas and Dysvik, 2009). At many organizations, complex development systems allow workers to take their share in the responsibility for their career and personal development, co-decide about the direction of their actions, monitor and readjust their development plans (Roe, 2014). The ingredients of worker's development, the inter- nal programs and systems that support employees are the key components in a strategy for internal quality of service in high-contact settings (Hallowell \& Schlesinger, 2000). Current service strategies that reflect the dimensions of employee development are driving employee outcomes such as productivity and satisfaction (Goldstein, 2009). Employees who believe that their organization is committed to providing skill and competence development should reciprocate by way of organizational commitment and job satisfaction (Lee and Bruvold, 2003).

Understanding of factors leading to job satisfaction of workers is important for the successful management of organizations (Kowal and Roztocki, 2015a), as it can also influence other aspects of human life, like family satisfaction (Ford, et al., 2007). According to Ghazzawi (2010), the major influencer of job satisfaction is the possibility to grow, regardless of gender.

Some other studies, like Sumner and Niederman (2003) noted similarities in job satisfaction for both genders, reflected in salary expectation, as opposite to the findings of Kowal and Roztocki (2016), who observed the dissatisfaction with pay among Polish IT and other high tech professional, expressed stronger in a studied group of women. What is more, more than half of the respondents from the Polish IT sector were unsatisfied with their promotion prospects (Kowal and Roztocki, 2015b).

Nevertheless, the satisfaction and development of an employee plays crucial role in a healthy employment relationship, as the responsibility to satisfy the other's needs in a form of reciprocal arrangement lies both in the domain of an employee and its direct leader (Ungemah, 2015).

\subsection{Leadership}

The successful operation of any organization depends on its effective leadership (Paliszkiewicz, et al., 2015) and has direct impact on job satisfaction (Tabvuma, et al., 2015). Effective leadership may be critical for employees in planning and realizing their career paths, influencing and motivating their daily performance and work values (Grojean, et al., 2004; Barling and Kelloway, 2001). It needs to be based on strategic approach to defining and developing 
workers' skills, adjusted to organizational and individual objectives, motivating and supporting people in the organization and inspiring them by example (Szczepanska and Wisniewska, 2012), so as the acquisition and knowledge management (KM) (Paliszkiewicz, 2007).

Among the modern leadership theories, we can differentiate the transactional and transformational relationship approaches. Transactional leadership focuses on leader-worker exchange, in the form of rewards, benefits, and self-interest (Gill, 2006), whereas the transformational leadership emphasizes the inspiration and motivation of followers to perform the best for the company (Kelloway and Barling, 2000).

Transactional leadership functions better for the Information Technology (IT) and KM systems' initiation rather than transformational leadership (Bryant, 2003). Leadership in business has become more than just an approach or attitude, as it is now a social process requiring effort from the team leader, as well as from team members on one another (Pearce, et al., 2009). Avolio, et al. (2009) claimed that currently, the collective and shared leadership at the teambased structures is present in organizations, taking over the lace of the old hierarchical approaches.

Senior leaders are sometimes not equipped with relevant and sufficient information to make effective decisions in a dynamic, complex environment (Pearce and Conger, 2003, p.2), therefore shared and distributed leadership take more and more importance. It is the only way to manage talents effectively, learn lessons from bad and good experiences and thoroughly understand current situation (Phillips and Loy, 2008).

One of the key challenges for many middle level managers is to properly implement the business goals laid out by their direct supervisors, that is, the senior managers (Yang, et al., 2010). The World Economic Forum has discovered in its Survey on the Global Agenda that according to $86 \%$ of respondents, we are facing the global leadership crisis today (WEF, 2014). The "leadership crisis", as addressed by some actors (Forbes, 2013), has been caused by the competition for talent recruitment, retirement challenges, transformations in the work environment and poor organizational practices in selecting, identi- fying, and developing talent (CCL, 2015). On the other hand, other sources claim that "There is no shortage of leaders, and perhaps not even a crisis of leadership. There is a shrinking of collective imagination, a crisis of purpose - and much leadership development, with its overemphasis on leaders' skills and styles, is complicit in it." (Harvard Business Review, 2014).

Nevertheless, leadership might be hindered by multiple internal and external constraints (Kulakowska, et al., 2012), like the opposition of workers to change, financial means (Zebrowski, et al., 2014). Some unethical, charismatic leaders often fall into the trap of pseudo-transformational leadership, based on illegitimate values and idealized influence and inspirational motivation (Barling, et al., 2008). It may pose multiple risks for the presence and performance of team members, including delegation, training, recruitment (Phelps, et al., 2007), and can hinder relations inside and outside company (Cope, et al., 2011). It can also influence the problemsolving process (Ospina, 2017) that remain a key focus for many organizations of the modern offshore services industry (Kedziora, et al., 2017b). As researchers tend to be focused on the long-run personal development (Coles, 1996), the other issues researched by academia in the context of leadership include race, ethnicity, social order and socioeconomic background (Hoyt \& Kennedy, 2008).

\subsection{Polish BPO/SSC industry as a work envi- ronment}

Business process offshoring can be explained as transferring some operational activities to an organization based in a different country (Doh, et al., 2009). In the Central and Eastern Europe (CEE) region, including Poland, majority of investments are originating from geographically close locations (nearshoring) (Kedziora, et al., 2017a). They are mostly stipulated by the reduction of operational expenses, availability of skillful human capital and strive for process improvement possibilities (Herath \& Kishore, 2009).

The attractiveness of Poland on the global sourcing map has been strong, as expressed in the latest A.T. Kearney Global Service Location Index (2017), 
where Poland assumed the $12^{\text {th }}$ place in the global map of sourcing destinations. Moreover, the latest Tholons ranking listed Cracow as the $8^{\text {th }}$ "top outsourcing destination" in the world (Tholons, 2017). Although initially, the transition economies of the Visegrad group (V4) that are Poland, Hungry, Czech Republic and Slovakia have been used as a provider of basic processes, being treated as low materials and technology exporters (Jürgens and Krzywdzinski, 2009), their position has been gradually changing onto the hub of modern services' providers (Hardy, 2007).

As stated by Deloitte (2016), "the market will continue to produce services that bundle process, technology, and support via cloud, as-a-service, and capability-based service models". At the same time, the compound growth rate of employment at the level of $19 \%$ annually has been a strong challenge not only for the investors and top management, but also for the recruitment and human development actors of the industry (ABSL, 2017). The key reason behind many offshoring decisions is the access to larger talent pool of human resources at a remote location (Kedia \& Mukherjee, 2009).

In the context of rapid expansion and further growth plans, Polish corporations of business process outsourcing (BPO) and shared services centers (SSC) stand up on and strongly emphasize the importance of employee development that is under the direct responsibility of leadership crew (Antal, 2017).

The industry is seen by young, dynamic professionals as attractive, due to the initiatives implemented by many organizations from the areas of language skills and soft skill trainings (Eurostudent, 2017). More and more firms seriously care for the workers to be rested and have opportunity to take part in various initiatives after hours, so as to work in a pleasant atmosphere (Kiewlicz, 2018).

Additional motivating benefits, like sports cards, private healthcare and lunch vouchers have become a standard in many organizations (ProProgressio, 2018). More and more universities are organizing degrees and programmes in cooperation with the $\mathrm{BPO} / \mathrm{SSC}$ industry, to supply the industry with the well-prepared talent pool (Piotrowicz, 2015a).

\section{Research method}

The research focused on practical aspects of the Polish offshore delivery centers and aimed for exploring the situation of the industry's employees, from the perspective of their personal development and direct leader's perception in their organizations.

The theoretical review formed a base for writing the paper and the sources' selection was done through the renowned databases, such as Research Gate, Science Direct, Wiley Online Library and Web of Knowledge (ThomsonReuters). The search terms included the words under the research scope, such as: "outsourcing", "offshoring", "transition", "leadership", "development", "employee", "potential", "Poland". The authors selected the publications based on their title, date of publishing, abstract and number of quotations, to ensure their positioning at the studied discipline (Tranfield, et al., 2003).

The review was supposed to explore the current research and understand the multidimensional views on the studied topic, constituting the start for further research actions. Following the insights provided by Pierce and Maurer (2009), the questionnaire was developed, as the authors wanted to approach the studied topic from the perspective of personal development and leadership perception. The structure and content of the questionnaire (Appendix 1) is derived from the aspects that fell under the interest of the authors of this pilot study.

The quantitative, empirical approach was assumed in the collection of data that took place between September - December 2017. The applied collection method was non-discriminative snowball sampling, where each recruited participant in the survey recruits more participants (Etikan, et al., 2016).

As a result of the conducted research, the primary material was obtained in the form of completed questionnaires. Next, the data was transferred to the information sheets using Microsoft Excel and SPSS (Statistical Package for Social Sciences) to analyze and process the data statistically (see: Weaver, et al., 2017). First, the distributions were analyzed using descriptive statistics methods. In the next step when justified, an attempt was made to determine the possibility of existence of relationships between selected 
variables, applying cross-balances and determining boundary values.

The basis for the study of the relationship between features was the table of independence (contingency), by means of which a minimum of two features was arranged at the same time. This table consisted of " $r$ " rows and "s" columns. Each row and associated column corresponding to individual variants of the $\mathrm{X}(\mathrm{Y})$ feature. The interior of the contingency table is the number $n_{i j}$ and the elements of the sample that have the $i$-th variant of the feature:

$$
\mathrm{X}(\mathrm{i}=1,2, \ldots, \mathrm{r})
$$

and $j$-th variant of the characteristic:

$$
\mathrm{Y}(\mathrm{j}=1,2, \ldots, \mathrm{s}) \text {. }
$$

The contingency tables made it possible to verify the partial hypotheses about the existence of stochastic independence between the variables $\mathrm{X}$ and $\mathrm{Y}$. To verify the H0 hypothesis about the stochastic independence of variables, the $\chi^{2}$ (chi-square) statistics was used. It uses the methodology of testing hypotheses about the statistical significance of the relationship between variables using the SPSS computer program, the value of statistics and significance levels for the analyzed selected variable pairs were determined.

Verification of the statistical significance of the observed relationships of variables consisted in checking whether for the value of the $\chi^{2}$ statistics of a given pair of analyzed variables, the value of the asymptotic significance parameter is less than 0.05 . If so, the observed relationship between variables could be considered as statistically significant. Despite the limited sample size, this approach allowed for the results obtained from the empirical material to constitute the basis for verifying the validity of the hypothesis of the conducted study on the existence of possible dependencies (see: Field, 2013).

In total, the survey has been sent to 319 persons, working for 17 teams and employed in 32 companies of the Polish BPO/SSC industry, which constitutes $4 \%$ of the total 748 centers in the country (ABSL, 2017). The response rate was $16 \%$ (51 responses received). In the questionnaire, both single-choice and multiple-choice answers, as well as the Likert scaling was used (see Appendix 1). Interlocutors had unlimited time for response and the survey has been anonymous, so that all the answers would be comfortably considered.

As for more details of the study sample, the majority of respondents were working for Information Technology companies (27), Customer support (11), Banking (6), Accounting (3) and Logistics (3). Only one respondent worked in some other industry. Majority of the respondents (44 persons) worked for the organizations having more than 501 employees, and 7 of them were employed at medium organizations (101-500 employees). This is above the average headcount at Polish business services centers that equals 226 (the median being 90) (ABSL, 2017).

As for the type of ownership of the offshore organizations, most respondents (38) worked in the captive offshore delivery centers, and only 13 (25\%) were engaged in the outsourcing operations. It corresponds to the general situation in Poland, where $40 \%$ of operations are provided to external clients, $27 \%$ in-house, and $23 \%$ in a hybrid model (both internal and external customers).

As for the employee's time of employment in the current company, only 7 respondents (14\%) have been working at the current company for more than 5 years, whereas most of them have been employed between $1-5$ years $(47 \%)$, and 20 of them $(39 \%)$ have been working there for less than a year. It can be related to the entire BPO/SSC industry that is still at its not so mature, as its intensive growth has been commenced in the 2000s (PIaFIA, 2016), but might also be linked to quite substantial turnover of workers in this industry which is observed especially in the Information

Technology area as innovative technologies enforce changes and at the same time change becomes an immanent part of professional development in IT.

\section{Findings and discussion}

The findings of this work highlight the importance of employee development and direct leader's perception in the Polish BPO/SSC offshore delivery centers. The compiled presentation of responses to the questions asked is followed by the interpretation and discussion upon them. 
Table 1. Perception of personal development factors (Source: own elaboration)

\begin{tabular}{|l|l|l|l|l|l|}
\hline $\begin{array}{r}\text { Question: How do you agree with the follow- } \\
\text { ing sentence? }\end{array}$ & $\begin{array}{c}\text { Strongly } \\
\text { Disagree }\end{array}$ & Disagree & Neutral & Agree & $\begin{array}{c}\text { Strongly } \\
\text { Agree }\end{array}$ \\
\hline $\begin{array}{l}\text { Q5: I feel I have chances to develop myself } \\
\text { at work. }\end{array}$ & $0(0 \%)$ & $7(14 \%)$ & $8(16 \%)$ & $24(47 \%)$ & $12(24 \%)$ \\
\hline $\begin{array}{l}\text { Q6: I feel encouraged to proactively initiate } \\
\text { improvements in daily work. }\end{array}$ & $6(12 \%)$ & $19(37 \%)$ & $11(22 \%)$ & $17(33 \%)$ & $6(12 \%)$ \\
\hline $\begin{array}{l}\text { Q7: I feel well trained and knowledgeable } \\
\text { to do my work. }\end{array}$ & $4(8 \%)$ & $39(76 \%)$ & $0(0 \%)$ & $5(10 \%)$ & $3(6 \%)$ \\
\hline $\begin{array}{l}\text { Q8: I feel I have chances to develop myself } \\
\text { at work? }\end{array}$ & $2(4 \%)$ & $5(10 \%)$ & $16(31 \%)$ & $21(41 \%)$ & $7(14 \%)$ \\
\hline $\begin{array}{l}\text { Q9: I feel my work and development goals } \\
\text { are clearly defined. }\end{array}$ & $7(14 \%)$ & $7(14 \%)$ & $20(39 \%)$ & $11(22 \%)$ & $6(12 \%)$ \\
\hline $\begin{array}{l}\text { Q14: I feel that the work-relations among my } \\
\text { team members are professional } \\
\text { and positive. }\end{array}$ & $2(4 \%)$ & $7(14 \%)$ & $21(41 \%)$ & $17(33 \%)$ & $4(8 \%)$ \\
\hline $\begin{array}{l}\text { Q15: I feel that my life-work balance } \\
\text { is at the right condition. }\end{array}$ & $9(18 \%)$ & $4(8 \%)$ & $18(35 \%)$ & $20(39 \%)$ & $0(0 \%)$ \\
\hline
\end{tabular}

\subsection{Employee development}

As for the personal development possibilities, majority of the respondents related to chances for selfdevelopment at work and expressed positive perception. Only $14 \%$ felt that they are not able to personally grow, whereas $71 \%$ have chosen either 'Agree' or 'Strongly Agree' option. When comparing the answers to Question 5 with the time of employment, it can be concluded that there is a weak relationship between these two variables (the value of $\chi 2=6.680$ is statistically significant, although the existing relationship is weak $\mathrm{p}<0.05$ ). It is a good signal from the perspective of this paper's general outlook, as it can be seen that the better employees perceive their development possibilities, the longer they may stay at the same company.

As for Question 6, initiation of improvements in daily work, we can conclude that most of the respondents claimed that they did not feel encouraged towards initiatives, and proactive proposals of new solutions/actions at the team ( 25 negative responses against 23 positive, and 11 neutral). It is not a good signal, as it might be a substantial challenge and indicate that BPO industry limits employees' pro-activeness. This state confirms the existence of the relationship between responses to Question 6 and the time of employment of respondents in a given company (value $\chi^{2}=2.461$ is statistically significant and the existing relationship is very strong $p>0.5$ ). Employees should be encouraged to be proactive to help this industry and entire country strengthen its innovativeness, for there is still room for improvement in the light of Poland assuming rank 48 in the latest Global Innovation Index (Dutta, Lanvin, and Wunsch-Vincent, 2017).

As for Question 7, vast majority of respondents claimed that they do not feel knowledgeable and well-trained for their daily duties. Statistical analysis confirms the existence of weak dependencies between the knowledge level and the length of work in companies (value $\chi^{2}=6,049$ is statistically significant, and the existing relationship $\mathrm{p}>0.05$ ). This is vital concern, as knowledge management is a key aspect of the workers' personal development that should be managed strategically (Liebowitz, 2012). 
Table 2. Perception of direct leader engagement (Source: own elaboration)

\begin{tabular}{|l|l|l|l|l|l|}
\hline $\begin{array}{c}\text { Question: How do you agree } \\
\text { with the following sentence? }\end{array}$ & $\begin{array}{c}\text { Strongly } \\
\text { Disagree }\end{array}$ & Disagree & Neutral & Agree & $\begin{array}{c}\text { Strongly } \\
\text { Agree }\end{array}$ \\
\hline $\begin{array}{l}\text { Q10: I feel my direct leader } \\
\text { seriously cares for my professional } \\
\text { development. }\end{array}$ & $9(18 \%)$ & $11(22 \%)$ & $17(33 \%)$ & $10(20 \%)$ & $4(8 \%)$ \\
\hline $\begin{array}{l}\text { Q11: I feel my direct leader } \\
\text { is treating me fairly. }\end{array}$ & $3(6 \%)$ & $9(18 \%)$ & $5(10 \%)$ & $16(31 \%)$ & $18(35 \%)$ \\
\hline $\begin{array}{l}\text { Q12: I feel my direct leader } \\
\text { is motivating me. }\end{array}$ & $7(14 \%)$ & $17(33 \%)$ & $2(4 \%)$ & $20(39 \%)$ & $5(10 \%)$ \\
\hline $\begin{array}{l}\text { Q13: I trust my direct leader } \\
\text { and co-workers. }\end{array}$ & $5(10 \%)$ & $19(37 \%)$ & $10(20 \%)$ & $4(8 \%)$ & $13(25 \%)$ \\
\hline
\end{tabular}

As for Question 8, we can observe that here also, vast majority of respondents felt that in general, their work offers them the chance to develop themselves. It is directly answering the first research question addressed in this paper. Considering the personal development opportunities in the aspect of the length of work time in the company existence of a certain relationship can be observed (the value of $\chi^{2}=$ 15.574 is statistically significant at $\mathrm{p}<0.05$ ), although it is quite weak. This is actually quite reasonable as personal development possibilities next to salary is treated as most important motivating factor. At the same time, well trained and crosscompetence workers is the most valuable asset of companies in BPO industry.

As for Question 9, it is interesting that most of the respondents have remained neutral as for the perception of clearly defined development goals. Statistical analysis confirms the existence of weak dependencies between the clearly defined development goals and the length of employment (value $\chi^{2}=1,802$ is statistically significant, and the existing relationship is significant $p>0.5$ ). This may be a result of the large organizations they work for and permanent changes in terms of structure, processes, technologies and strategies mainly imposed by headquarters.

As for Question 14, we can observe that for the majority of respondents, the relations inside their team are either neutral or positive. Conducted analysis conform that more often the relations between team members are professional and positive the longer they work, which confirms the existence of a relationship (value $\chi^{2}=7.547$ is statistically significant, and the existing relationship $\mathrm{p}>0.05$ ). Such response is reasonable as good work-relations among team members may (and should) compensate the goal and test orientation, despite the stressful work environment they are exposed to.

As for Question 15, most of the respondents are positive, pointing at the right (or neutral) balance between work and private life. Statistical analysis confirmed the weak relationship (value $\chi^{2}=4.040$ is statistically significant, and the existing relationship $\mathrm{p}<0.05)$ between the sense of balance between personal life and work, and the length of employment. It is very important from the perspective of a long run well-being of workers, and impact on society. On the other hand, symptomatically, here is lack of "Strongly Agree" response and considerable number of "Strongly Disagree" responses, which indicates that BPO industry is still very demanding when it came to dedication.

\subsection{Leadership}

As for Question 10, we can see that most of the responses do not express the perception of the direct leader being engaged in the personal development plan of an employee. Analysis confirm the existence of some dependencies between variables: leader's engagement in employee's personal development 
plan and the length of employment (value $\chi^{2}=$ 1.478 is statistically significant and the existing relationship is significant $p>0.5$ ). Similarly, to the previous question, such responses here may be the result of permanent changes in large organization the employees work for. Side effects of this situation are relative frequent changes in line management workforces which is not good for stable professional development of their teams.

As for Question 11, it is important to note that most of the employees perceive their direct leader to be treating them fairly, despite his/her low engagement in their development effort. Such response is a result of mature organizational culture as most of the BPO industry companies come from western civilization (at least their high management), where managersubordinate relations are maintained at the appropriate level and such approach is propagated down to mid and low-level management structures and relations across the company. Statistical analysis confirms the existence of dependence (value $\chi^{2}=$ 2,585 is statistically significant and the existing relationship is significant $p>0.05$ ). This means that the longer the employees work in a given company, the more often they have a sense of fair treatment by the direct leader.

As for Question 12, we can note that most of the respondents do not feel their direct leader to have motivating power. Statistical analysis confirms the existing relationship between the length of employment and the sense of motivation (value $\chi^{2}=$ 6.419 is statistically significant and the existing relationship is very significant $p>0.05$ ). It might be influenced by the poor perception of knowledge management that has a strong impact on the effects of empowering leadership (Srivastava, et al., 2006).

As for Question 13, we can see that the trust level among co-workers and direct leader is perceived as high. Analysis confirms the relationship between trust to the superior and seniority (value $\chi 2=5.497$ is statistically significant and the existing relationship is significant $p>0.05$ ). It can be linked to the knowledge management, as the trust among company members can evolve as an output of the knowledge creation process (von Krogh, et al., 2011).

\section{Conclusions}

This work aimed at researching a formerly unexplored aspect of this phenomenon that is the perception of employee development and direct leader's engagement in the context of Polish offshore modern services delivery centers. The results presented in "Findings and Discussion" section partially confirm general assumptions, like size of BPO industry organizations (mainly big companies), number of opportunities to develop on professional level when working for BPO or fact that next to salary possibility to learn new skills is one of main motivating factors. However, some results seem to be unobvious, for example, personal motivation as most problematic area in daily work, communication as most rated challenging area or promotion not treated as important motivating factor.

As for the first research question that concerned the perception of personal development opportunities, it has been found that in general, workers expressed its positive perception. Moreover, they expressed that in their opining the life-work balance is on a right state, and the relations inside team members are neutral or positive. Nevertheless, although their work offers them the chance to develop themselves, they do not feel enough trained and knowledgeable for their duties, nor do they feel to be encouraged to be proactive and welcome with new ideas. Therefore, the strengthening of knowledge management and promoting the innovative, continuous improvement mind-set among organization members can be recommended to the managerial community of the Polish BPO/SSC industry.

The second question concerned the employees' perception of direct leadership engagement. The employees expressed negative feelings towards their supervisor's genuine engagement in their personal development plan, as well as negative perception of their leader's motivating power. At the same time, their answers prove that they feel treated fairly and they trust their direct leaders. Thus, it can be recommended for the leaders to build on this trust and engage more in motivating and conscious planning of each employee's personal development.

The findings deepen and enrich scientific knowledge in the field of employee development in the context 
of leadership in the Polish offshore delivery centers of the $\mathrm{BPO} / \mathrm{SSC}$ industry. Therefore, this pilot study is of an exploratory character. As for the limitations, the sample of respondents was not representative, so the conclusions based on it need to be supported carefully. Thus, there is still a potential for the opportunities for comparative studies, conducted with both quantitative and qualitative work among researchers interested in the topic.

\section{References}

[1] ABSL Association of Business Services Leaders, 2017. Business Services Sector in Poland 2017. [online] Available at: http://absl.p1/ publications / [Accessed 22 January 2018].

[2] Antal, 2017. Nowy wizerunek korporacji. Wprowadzenie do SSC/BPO (A New Corporate Image. Introduction to SSC / BPO) [online] Available at: https://antal.pl/trendy/artykulyeksperckie/1567-nowy-wizerunek-korporacji [Accessed 20 January 2018].

[3] Barling, J., Weber, T., Kelloway, E.K., 1996. Effects of Transformational Leadership Training on Attitudinal and Financial Outcomes: A Field Experiment, Journal of Applied Psychology, 81(6), pp.827-832.

[4] Barling, J., Christie, A.M., Turner, N., 2008. Pseudo-transformational Leadership: Towards the Development and Test of a Model. Journal of Business Ethics, 81(4), pp.851-861.

[5] Bryant, S.E., 2003. The Role of Transformational and Transactional Leadership in Creating, Sharing and Exploiting Organizational Knowledge. Journal of Leadership and Organizational Studies, 9(4), pp.32-44.

[6] Coles, C., 1996. Approaching Professional Development. J. Contin. Educ. Health Prof., 16, pp.152-158.

[7] CCL Centre for Creative Leadership, 2015. The Leadership Gap: How to Fix What Your Organization Lacks [online] Available at: https://www. ccl.org/articles/white-papers/leadership-gapwhat-you-still-need/ [Accessed 12 January 2018].

[8] Cope, J., Kempster, S., Parry, K., 2011. Exploring Distributed Leadership in the Small Business
Context. International Journal of Management Reviews, 13(3), pp.270-285.

[9] Deloitte, 2016. Global Outsourcing Survey 2016: Outsourcing Accelerates Forward. [online] Available at: www.deloitte.com [Accessed 22 January 2018].

[10] Deloitte, 2017. Deloitte Global Human Capital Trends 2017 [online] Available at: www.deloitte.com [Accessed 26 January 2018].

[11] Doh, J.P., Bunyaratavej, K., Hahn, E.D., 2009. Separable but not Equal: the Location Determinants of Discrete Services Offshoring Activities. Journal of International Business Studies, 40(6), pp.926-943.

[12] Dutta, S., Lanvin, B., Wunsch-Vincent, S., 2018. The Global Innovation Index 2017: Innovation Feeding the World [online] Available at: https://www.globalinnovationindex.org [Accessed 26 February 2018].

[13] Etikan, I., Alkassim, R., Abubakar, S., 2016. Comparison of Snowball Sampling and Sequential Sampling Technique. Biometrics \& Biostatistics International Journal, 3(1), pp.1-2.

[14] Eurostudent, 2017. Rozwój w Shared Service Centers i Business Process Outsourcing (Development in Shared Service Centers and Business Process Outsourcing) [online] Available at: https://www.eurostudent.pl/rozwoj-w-sharedservice-centers-i-business-process-outsourcing/ [Accessed 27 January 2018].

[15] Field, A., 2013. Discovering Statistics Using IBM SPSS Statistics. Sage Publications, London, the UK.

[16] Ford, M., Heinen, B., Langkamer, K.L., 2007. Work and family satisfaction and conflict: A meta-analysis of crossdomain relations. Journal of Applied Psychology, 92(1), pp.57-80.

[17] Gill, R., 2006. Theory and Practice of Leadership. London: Sage.

[18] Grojean, M.W., Resick, C.J., Dickson, M.W., Smith, D.B., 2004. Leaders, Values, and Organizational Climate: Examining Leadership Strategies for Establishing an Organizational Climate Regarding Ethics. Journal of Business Ethics, 55(3), pp.223-241.

[19] Ghazzawi, I., 2010. Gender Role in Job Satisfaction: the Case of the U.S. Information Technology Professionals. Journal of Organizational 
Culture, Communications \& Conflict, 14(2), pp.1-34.

[20] Goldstein, S.M., 2003. Employee Development: An Examination of Service Strategy in a High Contact Service Environment. Production and Operations Management, 12(2), pp.186-203.

[21] Hallowell, R.L., Schlesinger, A., 2000. The Service Profit Chain: Intellectual Roots, Current Realities, And Future Prospects. In Handbook of Services Marketing and Management, (eds: Swartz, T.A. and Iacobucci D.) Sagepublications, Thousand Oaks, California.

[22] Hardy, J., 2007. The New Competition and the New Economy: Poland in the International Division of Labour. Europe-Asia Studies, 59(5), pp.761-777.

[23] Harvard Business Review, 2014. There Is No Shortage of Leaders [online] Available at: https://hbr.org/2014/12/there-is-no-shortage-ofleaders [Accessed 27 January 2018].

[24] Herath, T., Kishore, R., 2009. Offshore Outsourcing: Risks, Challenges, and Potential Solutions. Information Systems Management, 26(4), pp.312-326.

[25] Hoyt, M.A., Kennedy, C.L., 2008. Leadership and Adolescent Girls: A Qualitative Study of Leadership Development. American Journal of Community Psychology, 42(3-4), pp.203-219.

[26] Jürgens, U., Krzywdzinski, M., 2009. Changing East-West Division of Labour in the European Automotive Industry. European Urban and Regional Studies, 16(1), pp.27-42.

[27] Kearney, A.T., 2017. The Widening Impact of Automation [online] Available at: https://www. atkearney.com/ [Accessed 27 January 2018].

[28] Kedia, B.L., Mukherjee, D., 2009. Understanding Offshoring: A Research Framework Based on Disintegration, Location and Externalization Advantages. Journal of World Business, 44(3), pp.250-261.

[29] Kedziora, D., Kraslawski, A., Kärri, T., 2016. Offshored Service Cost Model as a Key PostTransition Challenge. Journal of International Studies, 9(3), pp.207-218.

[30] Kedziora, D., Karri, T., Kraslawski, A., Halasa, M., 2017a. Nearshore Service Transfers in the EU: Legal and Economic Issues. Economics and Sociology, 10(1), pp.290-309.
[31] Kedziora, D., Kraslawski, A., Kärri, T., 2017 b. Reengineering of Offshored IT Helpdesk Operational Model for Transitional Optimisation. International Journal of Management and Decision Making, 16(4), pp.375-406.

[32] Kedziora, D., Klamut, E., Kärri, T., Kraslawski, A., 2017c. Higher Education Offshoring as an Innovative Response to Global Learning Challenges. International Journal of Management, Knowledge and Learning, 6(2), pp.239-260.

[33] Kelloway, E.K., Barling, J., 2000. Knowledge Work as Organizational Behavior. International Journal of Management Reviews, 2(3), 287-304.

[34] Kiewlicz, R., 2018. Doktór: Rozwój centrów BPO i SSC będzie trwał (Doctor: The Development of BPO and SSC Centers Will Continue) [online] Available at: https://biznes.trojmiasto.pl /Doktor-Rozwoju-centrow-BPO-i-SSC-nadalbedzie-trwal-n120269.html [Accessed 26 January 2018].

[35] Kowal, J., Roztocki, N., 2015a. Job Satisfaction of IT Professionals in Poland: Does Business Competence Matter? Journal of Business Economics and Management, 16(5), pp.995-1012.

[36] Kowal, J., Roztocki, N., 2015b. Do Organizational Ethics Improve IT Job Satisfaction in the Visegrád Group Countries? Insights from Poland, Journal of Global Information Technology Management, 18 (2), pp.127-145.

[37] Kowal, J., Roztocki, N, 2016. Gender and Job Satisfaction of Information Technology Professionals in Poland. 49th Hawaii International Conference on System Sciences (HICSS), pp.3625-3634.

[38] Kułakowska, A., Piątkowski, Z., Żebrowski, W., 2012. Barriers for Empowerment in Organisations on the Basis of Surveys. Foundations of Management, 2(1), pp.41-54.

[39] Kuvaas, B., Dysvik, A., 2009. Perceived Investment in Employee Development, Intrinsic Motivation and Work Performance. Human Resource Management Journal, 19(3), pp.217-236.

[40] Lee, C.H., Bruvold, N.T., 2003. Creating Value for Employees: Investment in Training and Education. International Journal of Human Resource Management, 14(6), pp.981-1000.

[41] Liebowitz, J., ed., 2012. Knowledge Management Handbook. Collaboration and Social Net- 
working, CRC Press, Taylor and Francis Group, London, New York.

[42] Ospina, S.M., 2017. Collective Leadership and Context in Public Administration: Bridging Public Leadership Research and Leadership Studies. Public Administrateion Review, 77(2), pp.275287.

[43] Paliszkiewicz J., 2007. Knowledge Management: An Integrative View and Empirical Examination. Cybernetics and Systems, 38(8), pp.825836.

[44] Paliszkiewicz, J., Gołuchowski, J., Koohang, A., 2015. Leadership, Trust, and Knowledge Management in Relation to Organizational Performance: Developing an Instrument. Online Journal of Applied Knowledge Management, 3(2), pp.19-35.

[45] Pearce, C.L., Manz, C.C., Sims, H.P., Jr., 2009. Where do We Go from Here? Is Shared Leadership the Key to Team Success? Organizational Dynamics, 38(3), pp.234-238.

[46] Pearce, C.L., Conger, J.A., 2003. All Those Years Ago: the Historical Underpinnings of Shared Leadership. In Shared Leadership: Reframing the Hows and Whys of Leadership. (eds: Pearce, C.L. and Conger, J.A.), Sage Publications, Thousand Oaks, California.

[47] Phillips, D.T., Loy., J.M., 2008. Architecture of Leadership: Preparation Equals Performance. Annapolis, MD: Naval Institute Press.

[48] Phelps, R., Adams, R., Bessant, J., 2007. Life Cycles of Growing Organizations: A Review with Implications for Knowledge and Learning. International Journal of Management Reviews, 9(1), pp.1-30.

[49] PIaFIA Polish Information and Foreign Investment Agency, 2016. Business Services Sector in Poland. Gaining momentum [online] Available at: http://www.paih.gov.pl/publications/sectoral studies [Accessed 25 January 2018].

[50] Pierce, H.R., Maurer, T.J., 2009. Linking Employee Development Activity, Social Exchange and Organizational Citizenship Behavior. International Journal of Training and Development, 13(3), pp.139-147.

[51] Piotrowicz, W., 2015a. An Interview With Wiktor Doktór, Journal of Global Information Technology Management, 18(2), pp.146-152,
[52] Piotrowicz, W., 2015b. Information Technology and Systems in the Visegrád Group of Countries (Czech Republic, Hungary, Poland, and Slovakia): A Literature Review, Journal of Global Information Technology Management, 18(2), pp.77-93.

[53] Pro Progressio, 2016. Rozwoj sektora BPO/SSC $w$ Warszawie (Development of the BPO / SSC Sector in Warsaw) [online] Available at: http://www.proprogressio.pl/pl/fundacja/badania -i-raporty.html [Accessed 11 January 2018].

[54] Pro Progressio, 2018. Annual report 2017 [online] Available at: http://www.proprogressio .pl/pl/fundacja/badania-i-raporty.html [Accessed 11 April 2018].

[55] Roe, R.A., 2014. Using Competences in Employee Development. In: The Wiley Blackwell Handbook of the Psychology of Training, Development, and Performance Improvement (Eds: K. Kraiger, J. Passmore, N.R. Santos and S. Malvezzi), Wiley-Blackwell, Hoboken, New Jersey.

[56] Srivastava, A., Bartol, K., Locke, E.A., 2006. Empowering Leadership in Management Teams: Effects on Knowledge Sharing, Efficacy, and Performance. Academy of Management Journal, 49(6), pp.1239-51.

[57] Szczepańska, K., Wiśniewska, M., 2013. Human Performance Improvement in the Health Care Organizations. Results of Empirical Study in Poland. Foundations of Management, 4(2), pp.97108.

[58] Ungemah , J., 2015. Employee Development. In: Misplaced Talent, J. Ungemah (ed.).

[59] Tabvuma, V., Georgellis, Y., Lange, T., 2015. Orientation Training and Job Satisfaction: A Sector and Gender Analysis. Human Resource Management, 54(2), pp.303-321.

[60] Tholons, 2017. Tholons Services Globalization Index TM 2017. [online] Available at: http://www.tholons.com/TholonsTop100/ [Accessed 21 January 2018].

[61] Tranfield, D.R., Denyer, D., Smart, P., 2003. Towards a Methodology for Developing Evidence-Informed Management Knowledge by Means of Systematic Review. British Journal of Management, 14(3), pp.207-222.

[62] Weaver, K.F., Morales, V., Dunn, S.L., Godde, K., Weaver, P.F., 2017. Basics in SPSS. In: An 
Introduction to Statistical Analysis in Research (eds: K.F. Weaver, V. Morales, S.L. Dunn, K. Godde and P.F. Weaver). John Wiley \& Sons, Hoboken, New Jersey.

[63] WEF World Economic Forum, 2014. Survey on the Global Agenda 2014. [online] Available at: http://reports.weforum.org/ [Accessed 5 January 2018].

[64] von Krogh, G., Nonaka, I., Rechsteiner, L., 2012. Leadership in Organizational Knowledge Creation: A Review and Framework. Journal of Management Studies, 49(1), pp.240-277.

[65] Żebrowski, W., Piątkowski, Z., Kułakowska, A., Piątkowski, A., 2014. The Influence of the Management (Motivational) Function on the Implementation of New Concepts of Management in Business Practices. Foundations of Management, 6(1), pp.71-78.

\section{Appendix 1 - Survey}

1) Your job tasks are in the business domain of:

- Information Technology

- Banking

- Accounting

- Customer support

- HR/Payroll

- Logistics

- Other

2) In your organization there is currently the following number of employees:

- $1-100$

- $101-500$

- 501-1000

- 1001-2000

- over 2000

3) Do you work for external clients (from different company), or for internal workers of the same organization?

- External (outsourcing)

- Internal (in-house)
4) For how long have you been working in this organization?

- less than 1 year

- 1-5 years

- over 5 years

For Q5 to Q15, the 5-point Likert scale was used, with possible single answer: Strongly Disagree/ Disagree/ Neutral/ Agree/ Strongly Agree.

1) How do you agree with the following sentence: I feel I have chances to develop myself at work?

2) How do you agree with the following sentence: I feel encouraged to proactively initiate improvements in daily work?

3) How do you agree with the following sentence: I feel well trained and knowledgeable to do my work?

4) How do you agree with the following sentence: I feel I have chances to develop myself at work?

5) How do you agree with the following sentence: I feel my work and development goals are clearly defined?

6) How do you agree with the following sentence: I feel my direct leader seriously cares for my professional development?

7) How do you agree with the following sentence: I feel my direct leader is treating me fairly?

8) How do you agree with the following sentence: I feel my direct leader is motivating me?

9) How do you agree with the following sentence: I trust my direct leader and co-workers?

10) How do you agree with the following sentence: I feel that the work-relations among my team members are professional and positive?

11) How do you agree with the following sentence: I feel that my life-work balance is at the right condition? 